OPEN ACCESS

Edited by:

Brian Wickes,

The University of Texas Health Science Center at San Antonio, United States

Reviewed by:

Pilar Escribano, Instituto de Investigación Sanitaria

Gregorio Marañón, Spain

Jarrod R. Fortwendel, College of Pharmacy, University of Tennessee Health Science Center,

United States

Anastasia Litvintseva,

Centers for Disease Control and

Prevention (CDC), United States

*Correspondence:

Anuradha Chowdhary

dranuradha@hotmail.com

Jacques F. Meis

jacques.meis@gmail.com

Specialty section:

This article was submitted to

Fungal Pathogenesis,

a section of the journal

Frontiers in Cellular and Infection

Microbiology

Received: 01 August 2018 Accepted: 05 October 2018

Published: 23 October 2018

Citation:

de Groot T, Hagen F, Vreuls W Verweij PE, Chowdhary $A$ and Meis JF

(2018) Genotyping of Aspergillus

fumigatus in Formalin-Fixed

Paraffin-Embedded Tissues and

Serum Samples From Patients With Invasive Aspergillosis.

Front. Cell. Infect. Microbiol. 8:377.

doi: 10.3389/fcimb.2018.00377

\section{Genotyping of Aspergillus fumigatus in Formalin-Fixed Paraffin-Embedded Tissues and Serum Samples From Patients With Invasive Aspergillosis}

\author{
Theun de Groot ${ }^{1}$, Ferry Hagen ${ }^{1,2}$, Willem Vreuls ${ }^{3}$, Paul E. Verweij ${ }^{4,5}$, \\ Anuradha Chowdhary ${ }^{6 *}$ and Jacques F. Meis ${ }^{1,4,5 *}$ \\ 1 Department of Medical Microbiology and Infectious Diseases, Canisius Wilhelmina Hospital, Nijmegen, Netherlands, \\ ${ }^{2}$ Department of Medical Mycology, Westerdijk Fungal Biodiversity Institute, Utrecht, Netherlands, ${ }^{3}$ Department of Clinical \\ Pathology, Canisius Wilhelmina Hospital, Nijmegen, Netherlands, ${ }^{4}$ Centre of Expertise in Mycology Radboudumc/CWZ, \\ Nijmegen, Netherlands, ${ }^{5}$ Department of Medical Microbiology, Radboudumc, Nijmegen, Netherlands, ${ }^{6}$ Department of \\ Medical Mycology, Vallabhbhai Patel Chest Institute, University of Delhi, New Delhi, India
}

Invasive aspergillosis (IA) is a deep tissue infection with a high mortality occurring mostly in immunocompromised patients. To investigate the pathology of patients with IA it may be important to determine the genotype of the invasive isolate of Aspergillus, however available tissues for study are often formalin fixed paraffin embedded (FFPE). Although DNA has been successfully isolated from such tissues for species identification, genotyping of Aspergillus species on such tissues has not yet been performed. In this study we aimed to determine the genotype of Aspergillus fumigatus in FFPE tissue and serum samples from five patients with invasive aspergillosis using nine highly polymorphic short tandem repeat (STRAf) loci. FFPE lung and bronchial biopsies from all patients were successfully typed. By comparing the latter result with non-FFPE materials from non-sterile samples such as sputum, bronchoalveolar lavage and lung abscess, we found identical genotypes within three patients, while the two other patients had a dominant genotype shared among all sample types. Genotyping of serum samples was successful in two serum samples with galactomannan ratios of 4 and 5.6, but failed in serum samples with galactomannan levels $<0.5$. In addition, testing a subset of these materials with the AsperGenius multiplex qPCR assay, we did not find azole resistance mutations. With this STRAf assay, A. fumigatus from FFPE tissue and serum was successfully genotyped, allowing retrospective examination of $A$. fumigatus in culture negative patients with IA.

Keywords: Aspergillus fumigatus, molecular detection, molecular typing, paraffin embedded formalin fixed tissue, serum

\section{INTRODUCTION}

The genus Aspergillus consists of more than 300 species of spore-forming filamentous fungi, but only a few species are recognized as human pathogens (Paulussen et al., 2017). While healthy individuals are generally not affected, immunocompromised persons are at risk to develop invasive aspergillosis (IA) with high mortality rates (Ullmann et al., 2018). Aspergillus fumigatus is the most 
prevalent species within the genus Aspergillus and the major species causing this disease, although there are also other Aspergillus species, which can cause IA (Sugui et al., 2014).

The diagnosis of IA is challenging as its clinical symptoms, including fever, cough, respiratory secretions, and dyspnea are not specific for this disease. Readily available respiratory samples, like sputum and bronchoalveolar lavage (BAL) fluid, can be cultured or directly tested for the presence of Aspergillus species, however positive specimens may reflect environmental contamination or colonization of the airway instead of invasive infection (Rantakokko-Jalava et al., 2003; Springer et al., 2018b). To improve the quality of clinical studies, guidelines have been established by the European Organization for Research and Treatment of Cancer/Mycosis Study Group (EORTC/MSG) to diagnose IA by categorizing this invasive fungal disease in “proven," "probable," or "possible" (De Pauw et al., 2008). Proven IA requires the histopathological identification of hyphae in a needle aspiration or biopsy accompanied by tissue damage and culture from a tissue that is normally sterile, followed by identification of the Aspergillus. Probable IA is based on a combination of host factors, clinical features and mycological criteria, while with possible IA these mycological criteria are not required. Mycological criteria include the identification of Aspergillus species in respiratory samples or their cultures or the presence of galactomannan (GM) antigen, a component of the Aspergillus cell wall (Mennink-Kersten et al., 2004; Boch et al., 2016; Eigl et al., 2017), in serum, plasma, or BAL fluid (De Pauw et al., 2008). Due to difficulties to use these diagnostic criteria for intensive care patients, an additional classification of "putative" IA was established, which besides a positive culture of lower respiratory tract specimen, is based on clinical signs and host factors or mycological criteria (Blot et al., 2012).

Different Aspergillus species have variable susceptibility for antifungal drugs and therefore it is important to identify the species causing IA, preferentially using deep tissue biopsies to be certain that the fungus recovered is causing the infection. For histopathological purposes, such tissues are mostly fixed with formalin and embedded in paraffin (Ullmann et al., 2018). Microscopic examination is sometimes challenging, especially for Aspergillus species, leading quite frequently to an incorrect morphological diagnosis (Kung et al., 2018). Recent advances allowed the isolation of fungal DNA from formalin-fixed paraffin-embedded (FFPE) tissues and, using qPCR, the identification of the fungal pathogens to species level (O'Sullivan et al., 2003; Rantakokko-Jalava et al., 2003; Perlin and Wiederhold, 2017). This has also been shown for samples with Aspergillus (Salehi et al., 2016; Dannaoui et al., 2017; Dudakova et al., 2017; Barnes et al., 2018; Morio et al., 2018; Springer et al., 2018a). To obtain closer insight in the epidemiology and pathogenesis of IA, it is essential to characterize Aspergillus strains genetically from different tissues from patients with IA. Different high discriminatory typing techniques for A. fumigatus are available (de Valk et al., 2007). As human DNA is also present in tissue and serum samples, such genotyping assay should be species-specific, making AFLP (de Valk et al., 2007) and RISC (de Ruiter et al., 2007) typing unsuitable. In contrast, microsatellite typing using the STRAf assay only amplifies specific $A$. fumigatus targets and the method is highly discriminative (de Valk et al., 2005). In this study we investigated whether it is possible to genotype A. fumigatus with high-resolution STRAf typing (de Valk et al., 2005) in FFPE tissue and serum samples.

\section{MATERIALS AND METHODS}

\section{Patients}

Isolates, FFPE tissue and serum samples from five ICU patients (A-E) in the age of 58 to 67 years old, were collected. All five patients had histological proven IA and were treated with antifungals. An overview of the patients is given in Table 1.

\section{DNA Extraction From Serum and FFPE Tissue Samples}

DNA was extracted from $200 \mu \mathrm{l}$ serum using the High Viral Nucleic Acid Kit (Roche Diagnostics, Almere, The Netherlands) according to manufacturer instructions. For the FFPE lung and bronchial biopsies, 5 sections (thickness, $10 \mu \mathrm{M}$ ) were cut using a sterile microtome blade and transferred to a $2 \mathrm{ml}$ centrifuge tube. To remove paraffin wax, the samples were washed with 2 x $500 \mu \mathrm{l}$ xylene, 2 x $500 \mu \mathrm{l}$ ethanol absolute and $500 \mu \mathrm{l}$ acetone. The pellet was dried at $56^{\circ} \mathrm{C}$. Next, $300 \mu \mathrm{l}$ of Puregene cell lysis solution from Gentra Systems (Biozym B.V., Landgraaf, The Netherlands) and Proteïnase $\mathrm{K}$ was added and incubated overnight at $56^{\circ} \mathrm{C}$ with continue mixing. Following mechanical lysis by running the sample for $30 \mathrm{~s}$ at $6,500 \mathrm{rpm}$ in a MagNA Lyser instrument with MagNA Lyser Green Beads (Roche Diagnostics), DNA was purified using affinity chromatography and subsequently eluted with 10 mM Tris-HCl, 1 mM EDTA (Boom et al., 1990).

\section{A. fumigatus Isolates and DNA Extraction}

Samples obtained from patients were routinely cultured on Sabouraud agar for 7 days at 30 and $35^{\circ} \mathrm{C}$. A. fumigatus isolates were presumptively identified at the time of collection by macroscopic and microscopic characteristics and the ability to grow at $48^{\circ} \mathrm{C}$. The isolates were stored as spore suspensions in regular microbial freezing broth containing $12.5 \%$ ( $\mathrm{vol} / \mathrm{vol}$ ) glycerol at $-80^{\circ} \mathrm{C}$ until testing. The isolates were revived by scraping off part of the sample, plating on Sabouraud's agar and cultivated at $30^{\circ} \mathrm{C}$ until sporulation. DNA from A. fumigatus

TABLE 1 | Patients with histologically proven invasive aspergillosis.

\begin{tabular}{|c|c|c|c|c|c|}
\hline \multicolumn{2}{|c|}{ Patient Age } & Underlying disease & \multirow{2}{*}{$\begin{array}{l}\text { Diagnosis } \\
\text { Pulmonary } \\
\text { IA }\end{array}$} & \multirow{2}{*}{$\begin{array}{l}\text { Treatment } \\
\text { Itraconazole } \\
\text { caspofungin }\end{array}$} & \multirow{2}{*}{$\begin{array}{l}\text { Outcome } \\
\text { Died }\end{array}$} \\
\hline A & 67 & $\begin{array}{l}\text { COPD, Influenza pneumonia } \\
(\mathrm{ICU})\end{array}$ & & & \\
\hline B & 62 & $\begin{array}{l}\text { COPD, Legionella } \\
\text { pneumonia } \\
(\mathrm{ICU})\end{array}$ & $\begin{array}{l}\text { Disseminate } \\
\text { IA }\end{array}$ & $\begin{array}{l}\text { Itraconazole } \\
\text { caspofungin }\end{array}$ & Died \\
\hline C & 59 & $\begin{array}{l}\text { COPD, Lung carcinoma } \\
(\mathrm{ICU})\end{array}$ & $\begin{array}{l}\text { Pulmonary } \\
\text { IA }\end{array}$ & Caspofungin & Died \\
\hline D & 58 & COPD & $\begin{array}{l}\text { Subacute } \\
\text { IA }\end{array}$ & Itraconazole & Survived \\
\hline$E$ & 65 & COPD & $\begin{array}{l}\text { Pulmonary } \\
\text { IA }\end{array}$ & Itraconazole & Survived \\
\hline
\end{tabular}


TABLE 2 | Overview of typing results.

\begin{tabular}{|c|c|c|c|c|c|c|c|c|c|c|c|c|}
\hline \multirow[t]{2}{*}{ Pat. + no. } & \multirow[t]{2}{*}{ Origin } & \multirow[t]{2}{*}{ Day of isolation } & \multirow[t]{2}{*}{ Cultured isolate } & \multicolumn{9}{|c|}{ STRAf type } \\
\hline & & & & $2 A$ & $2 B$ & $2 \mathrm{C}$ & $3 A$ & 3B & $3 C$ & $4 \mathrm{~A}$ & 4B & $4 C$ \\
\hline A1 & Sputum & 0 & Yes & 25 & 22 & 19 & 28 & 9 & 27 & 10 & 9 & 5 \\
\hline $\mathrm{A} 2$ & Sputum & 2 & Yes & 25 & 22 & 19 & 28 & 9 & 27 & 10 & 9 & 5 \\
\hline A3 & Serum, GM 0.1 & 3 & No & neg & neg & neg & neg & neg & neg & neg & neg & neg \\
\hline A4 & Serum, GM 0.1 & 6 & No & neg & neg & neg & neg & neg & neg & neg & neg & neg \\
\hline A5 & Sputum & 7 & Yes & 25 & 22 & 19 & 28 & 9 & 27 & 10 & 9 & 5 \\
\hline A6 & Lung abscess & 7 & Yes & 23 & 21 & 8 & 46 & 9 & 6 & 8 & 9 & 5 \\
\hline A7 & Sputum & 7 & Yes & 25 & 22 & 19 & 28 & 9 & 27 & 10 & 9 & 5 \\
\hline A8 & Biopsy lung & 7 & No & \multicolumn{3}{|c|}{$>3$ genotypes* } & \multicolumn{3}{|c|}{$>3$ genotypes ${ }^{*}$} & \multicolumn{3}{|c|}{$>3$ genotypes ${ }^{*}$} \\
\hline A9 & $\mathrm{BAL}$ & 9 & Yes & 25 & 22 & 19 & 28 & 9 & 27 & 10 & 9 & 5 \\
\hline A10 & Biopsy lung & 9 & No & \multicolumn{3}{|c|}{$>3$ genotypes ${ }^{\star}$} & \multicolumn{3}{|c|}{$>3$ genotypes ${ }^{\star}$} & \multicolumn{3}{|c|}{$>3$ genotypes ${ }^{\star}$} \\
\hline A11 & Biopsy lung & 9 & No & neg & 22 & 19 & 28 & 9 & 27 & 10 & 9 & 5 \\
\hline B1 & Sputum & 0 & Yes & 18 & 12 & 8 & 28 & 10 & 18 & 9 & 8 & 5 \\
\hline B2 & Sputum & 1 & Yes & 18 & 12 & 8 & 28 & 10 & 18 & 9 & 8 & 5 \\
\hline B3 & Sputum & 3 & Yes & 18 & 12 & 8 & 28 & 10 & 18 & 9 & 8 & 5 \\
\hline B4 & Sputum & 7 & Yes & 18 & 12 & 8 & 28 & 10 & 18 & 9 & 8 & 5 \\
\hline B5 & Sputum & 10 & Yes & 18 & 12 & 8 & 28 & 10 & 18 & 9 & 8 & 5 \\
\hline B6 & Sputum & 14 & Yes & 18 & 12 & 8 & 28 & 10 & 18 & 9 & 8 & 5 \\
\hline B7 & Sputum & 16 & Yes & 18 & 12 & 8 & 28 & 10 & 18 & 9 & 8 & 5 \\
\hline B8 & Sputum & 20 & Yes & 18 & 12 & 8 & 28 & 10 & 18 & 9 & 8 & 5 \\
\hline B9 & Sputum & 30 & Yes & 18 & 12 & 8 & 28 & 10 & 18 & 9 & 8 & 5 \\
\hline B10 & Serum, GM 0.4 & 30 & No & neg & neg & neg & neg & neg & neg & neg & neg & neg \\
\hline B11 & Sputum & 31 & Yes & 18 & 12 & 8 & 28 & 10 & 18 & 9 & 8 & 5 \\
\hline B12 & Sputum & 35 & Yes & 18 & 12 & 8 & 28 & 10 & 18 & 9 & 8 & 5 \\
\hline B13 & Sputum & 38 & Yes & 18 & 12 & 8 & 28 & 10 & 18 & 9 & 8 & 5 \\
\hline B14 & $\mathrm{BAL}$ & 42 & Yes & 18 & 12 & 8 & 28 & 10 & 18 & 9 & 8 & 5 \\
\hline B15 & Ascitis fluid & 42 & Yes & 18 & 12 & 8 & 28 & 10 & 18 & 9 & 8 & 5 \\
\hline B16 & Serum, GM 4.0 & 43 & No & 18 & 12 & 8 & 28 & 10 & 18 & 9 & 8 & 5 \\
\hline B17 & Sputum & 43 & Yes & 18 & 12 & 8 & 28 & 10 & 18 & 9 & 8 & 5 \\
\hline B18 & Serum, GM 5.6 & 44 & No & 18 & 12 & 8 & 28 & 10 & 18 & 9 & 8 & 5 \\
\hline B19 & Biopsy lung & 44 & No & 18 & 12 & 8 & 28 & 10 & 18 & 9 & 8 & 5 \\
\hline C1 & Sputum & 0 & Yes & 21 & 25 & 18 & 27 & 12 & 7 & 21 & 10 & 8 \\
\hline $\mathrm{C} 2$ & Sputum & 0 & Yes & 18 & 20 & 15 & 28 & 11 & 21 & 26 & 26 & 8 \\
\hline C3 & Bronchial biopsy & 1 & No & neg & neg & 18 & 27 & 12 & 7 & neg & 10 & 8 \\
\hline C4 & Serum & 1 & No & neg & neg & neg & neg & neg & neg & neg & neg & neg \\
\hline C5 & Sputum & 4 & Yes & 18 & 28 & 15 & 16 & 10 & 19 & 8 & 8 & 5 \\
\hline C6 & Sputum & 5 & Yes & 21 & 25 & 18 & 27 & 12 & 7 & 21 & 10 & 8 \\
\hline C7 & Sputum & 21 & Yes & 21 & 25 & 18 & 27 & 12 & 7 & 21 & 10 & 8 \\
\hline C8 & Sputum & 25 & Yes & 21 & 25 & 18 & 27 & 12 & 7 & 21 & 10 & 8 \\
\hline C9 & Serum & 25 & No & neg & neg & neg & neg & neg & neg & neg & neg & neg \\
\hline C10 & Sputum & 32 & Yes & 21 & 25 & 18 & 27 & 12 & 7 & 21 & 10 & 8 \\
\hline C11 & Sputum & 39 & Yes & 21 & 25 & 18 & 27 & 12 & 7 & 21 & 10 & 8 \\
\hline C12 & Sputum & 42 & Yes & 21 & 25 & 18 & 27 & 12 & 7 & 21 & 10 & 8 \\
\hline C13 & Sputum & 45 & Yes & 21 & 25 & 18 & 27 & 12 & 7 & 21 & 10 & 8 \\
\hline C14 & Sputum & 46 & Yes & 21 & 25 & 18 & 27 & 12 & 7 & 21 & 10 & 8 \\
\hline C15 & Sputum & 49 & Yes & 21 & 25 & 18 & 27 & 12 & 7 & 21 & 10 & 8 \\
\hline C16 & Sputum & 54 & Yes & 21 & 25 & 18 & 27 & 12 & 7 & 21 & 10 & 8 \\
\hline C17 & Sputum & 61 & Yes & 21 & 25 & 18 & 27 & 12 & 7 & 21 & 10 & 8 \\
\hline C18 & Sputum & 63 & Yes & 21 & 25 & 18 & 27 & 12 & 7 & 21 & 10 & 8 \\
\hline C19 & Sputum & 68 & Yes & 21 & 25 & 18 & 27 & 12 & 7 & 21 & 10 & 8 \\
\hline
\end{tabular}


TABLE 2 | Continued

\begin{tabular}{|c|c|c|c|c|c|c|c|c|c|c|c|c|}
\hline \multirow[t]{2}{*}{ Pat. + no. } & \multirow[t]{2}{*}{ Origin } & \multirow[t]{2}{*}{ Day of isolation } & \multirow[t]{2}{*}{ Cultured isolate } & \multicolumn{9}{|c|}{ STRAf type } \\
\hline & & & & $2 A$ & 2B & $2 \mathrm{C}$ & $3 A$ & 3B & $3 C$ & $4 \mathrm{~A}$ & 4B & $4 C$ \\
\hline C2O & Sputum & 71 & Yes & 21 & 25 & 18 & 27 & 12 & 7 & 21 & 10 & 8 \\
\hline C21 & Sputum & 75 & Yes & 21 & 25 & 18 & 27 & 12 & 7 & 21 & 10 & 8 \\
\hline C22 & Sputum & 75 & Yes & 18 & 12 & 18 & 27 & 22 & 21 & 18 & 9 & 5 \\
\hline C23 & Serum & 76 & No & neg & neg & neg & neg & neg & neg & neg & neg & neg \\
\hline C24 & Sputum & 76 & Yes & 21 & 25 & 18 & 27 & 12 & 7 & 21 & 10 & 8 \\
\hline C25 & Serum & 77 & No & neg & neg & neg & neg & neg & neg & neg & neg & neg \\
\hline C26 & Sputum & 79 & Yes & 21 & 25 & 18 & 27 & 12 & 7 & 21 & 10 & 8 \\
\hline C27 & Sputum & 79 & Yes & 21 & 25 & 18 & 27 & 12 & 7 & 21 & 10 & 8 \\
\hline C28 & Bronchial biopsy & 79 & No & 21 & 25 & 18 & 27 & 12 & 7 & 21 & 10 & 8 \\
\hline D1 & Sputum & 0 & Yes & 11 & 12 & 17 & 26 & 21 & 21 & 14 & 8 & 5 \\
\hline D2 & $\mathrm{BAL}$ & 1 & Yes & 11 & 12 & 17 & 26 & 21 & 21 & 14 & 8 & 5 \\
\hline D3 & $\mathrm{BAL}$ & 1 & Yes & 11 & 12 & 17 & 26 & 21 & 21 & 14 & 8 & 5 \\
\hline D4 & $\underline{\text { Biopsy lung\# }}$ & 3 & Yes & 11 & 12 & 17 & 26 & 21 & 21 & 14 & 8 & 5 \\
\hline D5 & Lung abscess & 3 & Yes & 11 & 12 & 17 & 26 & 21 & 21 & 14 & 8 & 5 \\
\hline D6 & Serum & 4 & No & neg & neg & neg & neg & neg & neg & neg & neg & neg \\
\hline D7 & Serum, GM 0.2 & 4 & No & neg & neg & neg & neg & neg & neg & neg & neg & neg \\
\hline D8 & $\underline{\text { Biopsy lung }}$ & 4 & No & 11 & 12 & 17 & 26 & 21 & 21 & 14 & 8 & 5 \\
\hline E1 & $\mathrm{BAL}$ & 0 & Yes & 18 & 23 & 16 & 38 & 11 & 46 & 10 & 9 & 8 \\
\hline E2 & Bronchial biopsy & 0 & No & 18 & 23 & 16 & 38 & 11 & 46 & 10 & 9 & 8 \\
\hline
\end{tabular}

GM, galactomannan.

FFPE tissues are underlined.

"Genotypes from these samples differed from the genotypes found in the other samples.

\# Genotyping was performed on both culture as direct material. Outcome was identical.

spores was extracted and purified with the MagNA Lyzer and MagNA Pure LC Instruments (Roche Diagnostics) as previous described (de Valk et al., 2005).

\section{Genotyping Using the STRAf Assay}

Reaction conditions and PCR primers were as described (de Valk et al., 2005), with minor modifications as described below. With regard to the serum and tissue samples the volume of DNA was raised to $5 \mu \mathrm{l}$ for each sample, the total volume of the PCR reaction remained $25 \mu \mathrm{l}$. The number of cycles was increased to 40 during the amplification procedure. Electropherograms were analyzed using Fragment Profiler 1.2 software (GE Healthcare, Roosendaal, The Netherlands).

\section{AsperGenius Multiplex qPCR}

The AsperGenius multiplex qPCR assay (PathoNostics, Maastricht, the Netherlands) was used to detect Aspergillus species, A. fumigatus and A. terreus, and identify azole resistance CYP51A mutations $\mathrm{TR}_{34}, \mathrm{~L} 98 \mathrm{H}, \mathrm{Y} 121 \mathrm{~F}$ and $\mathrm{T} 289 \mathrm{~A}$ in A. fumigatus according to the instructions from the manufacturer and as described (Chong et al., 2015). The qPCR was performed on a LightCycler 480-II (Roche Diagnostics).

\section{Ethics}

Samples were collected during routine patient care and the study was retrospective, therefore it was determined by the local Institutional Review Board of the CWZ that ethical clearance was not indicated. As patient anonymity was maintained, written informed consent of participants was also not required.

\section{RESULTS}

From patient A, BAL, lung abscess aspirate and four sputa, collected within a week, were cultured and genotyped by analyzing the variability in length of 9 STRs in A. fumigatus (STRAf) The BAL and four sputa showed one identical genotype of $A$. fumigatus, while a different genotype was obtained from the lung abscess (Table 2). Additionally, two sera and three lung biopsies were obtained. The serum samples, which were GM negative, showed no signal with the STRAf assay. In two lung biopsies different genotypes were identified, as multiple peaks were present for all 9 STRAf markers. The genotype of the third lung biopsy was identical to the one found in the BAL and sputum. From patient B we genotyped $A$. fumigatus isolates from 13 sputa, an ascites fluid and a BAL. One A. fumigatus STRAf type was found for all cultures and this type was also detected in two serum samples, with GM ratios of 4.0 and 5.6, and FFPE lung tissue. STRAf typing was not successful for a serum sample with a GM index of 0.4 .

From patient $\mathrm{C}$, cultures of 22 sputum samples, isolated during a 9-week period, were STRAf typed. Nineteen of these A. fumigatus isolates were genotypically identical, while three isolates demonstrated three different genotypes. Two bronchial biopsies demonstrated a STRAf type identical to the 19 sputum 
TABLE 3 | Results of AsperGenius multiplex real-time PCR assay on subset of patient materials.

\begin{tabular}{|c|c|c|c|c|c|c|c|c|}
\hline \multirow[t]{2}{*}{ Patient + No. } & \multirow[t]{2}{*}{ Origin } & \multirow{2}{*}{$\begin{array}{c}\text { Ct } \\
\text { Aspergillus species }\end{array}$} & \multirow{2}{*}{$\begin{array}{c}\text { Ct } \\
\text { A. fumigatus }\end{array}$} & \multirow{2}{*}{$\begin{array}{c}\text { Ct } \\
\text { A. terreus }\end{array}$} & \multicolumn{4}{|c|}{ A. fumigatus CYP51A PCR } \\
\hline & & & & & $\begin{array}{l}\text { WT/ } \\
\text { TR }_{34}\end{array}$ & $\begin{array}{l}\text { WT/ } \\
\text { L98H }\end{array}$ & $\begin{array}{l}\text { WT/ } \\
\text { Y121F }\end{array}$ & $\begin{array}{l}\text { WT/ } \\
\text { T289A }\end{array}$ \\
\hline A3 & Serum, GM 0.1 & 35.49 & 38.60 & - & - & - & WT & WT \\
\hline A4 & Serum, GM 0.1 & 35.49 & 36.93 & - & - & WT & WT & WT \\
\hline A8 & Biopsy lung & 26.87 & 28.61 & - & WT & WT & WT & WT \\
\hline A10 & Biopsy lung & 30.80 & 32.55 & - & WT & WT & WT & WT \\
\hline A11 & Biopsy lung & 31.61 & 33.43 & - & WT & WT & WT & WT \\
\hline B10 & Serum, GM 0.4 & 31.83 & 32.44 & - & - & WT & WT & - \\
\hline B16 & Serum, GM 4.0 & 29.78 & 31.39 & - & \# & WT & WT & WT \\
\hline B18 & Serum, GM 5.6 & 32.41 & 33.93 & - & WT & WT & WT & WT \\
\hline B19 & Biopsy lung & - & - & - & & & & \\
\hline C3 & Bronchial biopsy & 32.55 & 34.36 & - & WT & WT & - & - \\
\hline C4 & Serum & - & - & - & & & & \\
\hline C9 & Serum & - & - & - & & & & \\
\hline C25 & Serum & 36.41 & 38.56 & - & WT & WT & WT & WT \\
\hline C28 & Bronchial biopsy & 26.76 & 28.78 & - & WT & WT & WT & WT \\
\hline D7 & Serum, GM 0.2 & - & - & - & & & & \\
\hline D8 & Biopsy lung & 30.70 & 32.45 & - & WT & WT & WT & WT \\
\hline E2 & Bronchial biopsy & 30.77 & 32.62 & - & WT & WT & WT & WT \\
\hline
\end{tabular}

-, Amplification not successful.

\#Melting curve differ.

cultures. Four GM negative serum samples of this patient were also negative in the STRAf assay. In patient D STRAf typing of five cultured A. fumigatus isolates from sputum, two BAL samples, lung tissue and a lung abscess yielded a genotype that was identical to the genotype obtained from FFPE lung tissue. Two serum samples from this patient were negative for STRAf typing. In patient $\mathrm{E}$ the STRAf type found in the culture from a BAL sample was identical to the one obtained from a FFPE bronchial biopsy (Table 2).

Finally, we investigated whether it was feasible to determine azole resistance in a subset of available FFPE tissue and serum samples using the AsperGenius multiplex qPCR assay. This assays allows detection of Aspergillus in clinical materials and subsequent identification of azole resistance mutations $\mathrm{TR}_{34}$, L98H, Y121F, and T298A in CYP51A in case of A. fumigatus positive sampes. From 10 samples with successful STRAf typing, 9 were found positive for both the Aspergillus species and A. fumigatus qPCR (Table 3). From 7 sera with unsuccessful STRAf typing (A3, A4, B10, C4, C9, C25, and D7), A. fumigatus was identified in 4 samples using the AsperGenius qPCR. There was no azole-resistance related mutation observed in the A. fumigatus positive samples.

\section{DISCUSSION}

This study demonstrated that it is technically feasible to genotype A. fumigatus directly from FFPE tissue samples from patients with proven IA without the need to cultivate the isolate. In three patients $(\mathrm{B}, \mathrm{D}$, and $\mathrm{E})$ we observed identical
STRAf types in all sample types, including sputa and BAL fluids, serum, and lung biopsies. In patient $\mathrm{C}$ a dominant genotype was found in cultures from sputa, which was also identified in lung tissue. In patient A, five of the six isolates had the same genotype as detected in one of the three lung biopsies. Remarkably, in the two other lung biopsies more than three STRAf types were found, suggesting mixed infection, a phenomenon described earlier (Kolwijck et al., 2016). Interestingly, another study found that from such mixed respiratory infections, only one strain might disseminate to distant organs (Escribano et al., 2017). Thus, in our study the genotype of $A$. fumigatus identified in non-sterile respiratory samples largely represented those found in deeper tissues. These results are in concordance with previous studies on fresh materials, in which A. fumigatus isolates obtained from deeper tissue were often identical to those from respiratory samples (de Valk et al., 2007).

A STRAf type from serum was only obtained from patient B. GM ratio in these serum samples was 4.0 and 5.6. In sera from patient $\mathrm{A}, \mathrm{C}$, and $\mathrm{D}$ GM ratios were $<0.5$ and STRAf typing was not successful. This finding suggests that successful STRAf typing in serum requires a certain threshold level of GM. A GM ratio threshold of $>0.5$ is one of the diagnostic criteria for classification of patients with IA (De Pauw et al., 2008; Boch et al., 2016; Eigl et al., 2017). Remarkable, only one out of four patients with proven IA exhibited a GM ratio of $>0.5$, suggesting that the sensitivity of this analysis in the diagnosis of IA is rather low. Indeed a recent study with twenty-six patients with proven/probable IA found that 
only $23 \%$ of patients exhibited serum GM ratio $>0.5$ (Boch et al., 2016). Then, we found that from sera with unsuccessful STRAf typing, four tested positive for A. fumigatus in the AsperGenius multiplex qPCR and three negative, demonstrating that in some situations STRAf typing is not successful despite the presence of $A$. fumigatus DNA. STRAf typing for these samples might be more successful if the multiplex PCR would be divided over monoplex PCRs, which normally enhances the individual STRAf signals. This was however not tested. Another possibility to improve STRAf typing from blood samples is the use of plasma instead of serum, as it was found that DNA concentrations are higher in plasma, leading to an increased sensitivity to detect A. fumigatus (White et al., 2015). Monoplex PCRs were also not performed for other samples, as only in one biopsy (C3) two dinucleotide repeats (2A and $2 \mathrm{~B})$ and one tetranucleotide repeat $(4 \mathrm{~A})$ could not be amplified, while the six remaining loci yielded good interpretable peaks. These loci showed identical repeat numbers as many other cultured isolates of this patient. Therefore, these sample were considered to be identical.

Finally, using the AsperGenius multiplex qPCR assay we investigated the potential presence of azole resistance markers $\mathrm{TR}_{34}, \mathrm{~L} 98 \mathrm{H}, \mathrm{Y} 121 \mathrm{~F}$, and T289A in lung biopsies and serum samples positive for A. fumigatus (Chong et al., 2015). While amplification for most samples was achieved, it did not succeed for sample B19, although genotyping was successful. This likely

\section{REFERENCES}

Barnes, R. A., White, P. L., Morton, C. O., Rogers, T. R., Cruciani, M., Loeffler, J., et al. (2018). Diagnosis of aspergillosis by PCR: clinical considerations and technical tips. Med. Mycol. 56, 60-72. doi: 10.1093/mmy/myx091

Blot, S. I., Taccone, F. S., Van den Abeele, A. M., Bulpa, P., Meersseman, W., Brusselaers, N., et al. (2012). A clinical algorithm to diagnose invasive pulmonary aspergillosis in critically ill patients. Am. J. Respir. Crit. Care Med. 186, 56-64. doi: 10.1164/rccm.201111-1978OC

Boch, T., Buchheidt, D., Spiess, B., Miethke, T., Hofmann, W. K., and Reinwald, M. (2016). Direct comparison of galactomannan performance in concurrent serum and bronchoalveolar lavage samples in immunocompromised patients at risk for invasive pulmonary aspergillosis. Mycoses 59, 80-85. doi: $10.1111 /$ myc. 12434

Boom, R., Sol, C. J., Salimans, M. M., Jansen, C. L., Wertheim-Van Dillen, P. M., and Van der Noordaa, J. (1990). Rapid and simple method for purification of nucleic acids. J. Clin. Microbiol. 28, 495-503.

Buil, J. B., Zoll, J., Verweij, P. E., and Melchers, W. J. G. (2018). Molecular detection of azole-resistant Aspergillus fumigatus in clinical samples. Front. Microbiol. 9:515. doi: 10.3389/fmicb.2018.00515

Chong, G. L., Van de Sande, W. W., Dingemans, G. J., Gaajetaan, G. R., Vonk, A. G., Hayette, M. P., et al. (2015). Validation of a new Aspergillus real-time PCR assay for direct detection of Aspergillus and azole resistance of Aspergillus fumigatus on bronchoalveolar lavage fluid. J. Clin. Microbiol. 53, 868-874. doi: 10.1128/JCM.03216-14

Dannaoui, E., Gabriel, F., Gaboyard, M., Lagardere, G., Audebert, L., Quesne, G., et al. (2017). Molecular diagnosis of invasive aspergillosis and detection of azole resistance by a newly commercialized PCR kit. J. Clin. Microbiol. 55, 3210-3218. doi: 10.1128/JCM.01032-17

De Pauw, B., Walsh, T. J., Donnelly, J. P., Stevens, D. A., Edwards, J. E., Calandra, T., et al. (2008). Revised definitions of invasive fungal disease from the european organization for research and treatment of cancer/invasive fungal infections cooperative group and the national institute of allergy and infectious diseases represented a false negative result, possibly resulting from lower DNA quality. In samples with $A$. fumigatus no resistance mutations were identified. In sample $\mathrm{B} 16$ the $\mathrm{TR}_{34}$ melting curve did not correspond with wildtype or mutant control. This sample was not further investigated by sequence analysis, so the cause of this discrepancy remains unknown. Amplification of resistance targets was not successful in 7 of 52 PCR reactions and these materials originated from three sera and a lung biopsy. The other six lung biopsies with $A$. fumigatus were successfully characterized, demonstrating a success rate of $86 \%$ for FFPE tissues, which is very similar to the performance of this assay in non-FFPE clinical materials (White et al., 2017; Buil et al., 2018; Postina et al., 2018).

In conclusion, the STRAf assay allows simultaneous detection as well as high discriminatory genotyping of A. fumigatus directly in FFPE tissue samples without the need for culture. This approach allows (retrospective) examination of A. fumigatus in patients with IA and might be used toward a better understanding of the pathogenesis of this disease.

\section{AUTHOR CONTRIBUTIONS}

TdG, FH, WV, PV, and JM acquisition, analysis and interpretation of the data. $\mathrm{TdG}$ and $\mathrm{FH}$ statistical analysis. TdG, FH, and JM drafted the manuscript. TdG, FH, WV, PV, AC, and JM reviewed and modified the manuscript.

mycoses study group (EORTC/MSG) consensus group. Clin. Infect. Dis. 46, 1813-1821. doi: 10.1086/588660

de Ruiter, M. T., de Valk, H. A., Meis, J. F., and Klaassen, C. H. (2007). Retrotransposon insertion-site context (RISC) typing: a novel typing method for Aspergillus fumigatus and a convenient PCR alternative to restriction fragment length polymorphism analysis. J. Microbiol. Methods 70, 528-534. doi: 10.1016/j.mimet.2007. 06.009

de Valk, H. A., Meis, J. F., Curfs, I. M., Muehlethaler, K., Mouton, J. W., and Klaassen, C. H. (2005). Use of a novel panel of nine short tandem repeats for exact and high-resolution fingerprinting of Aspergillus fumigatus isolates. J. Clin. Microbiol. 43, 4112-4120. doi: 10.1128/JCM.43.8.4112-4120.2005

de Valk, H. A., Meis, J. F., de Pauw, B. E., Donnelly, P. J., and Klaassen, C. H. (2007). Comparison of two highly discriminatory molecular fingerprinting assays for analysis of multiple Aspergillus fumigatus isolates from patients with invasive aspergillosis. J. Clin. Microbiol. 45, 1415-1419. doi: 10.1128/JCM. 02423-06

Dudakova, A., Spiess, B., Tangwattanachuleeporn, M., Sasse, C., Buchheidt, D., Weig, M., et al. (2017). Molecular tools for the detection and deduction of azole antifungal drug resistance phenotypes in Aspergillus species. Clin. Microbiol. Rev. 30, 1065-1091. doi: 10.1128/CMR.00095-16

Eigl, S., Hoenigl, M., Spiess, B., Heldt, S., Prattes, J., Neumeister, P., et al. (2017). Galactomannan testing and Aspergillus PCR in same-day bronchoalveolar lavage and blood samples for diagnosis of invasive aspergillosis. Med. Mycol. 55, 528-534. doi: 10.1093/mmy/myw102

Escribano, P., Muñoz, P., Montilla, P., Padilla, B., Bouza, E., and Guinea, J. (2017). Genotyping of Aspergillus fumigatus reveals compartmentalization of genotypes in disseminated disease after invasive pulmonary aspergillosis. $J$. Clin. Microbiol. 55, 331-333. doi: 10.1128/JCM.02037-16

Kolwijck, E., van der Hoeven, H., de Sevaux, R. G., Ten Oever, J., Rijstenberg, L. L., van der Lee, H. A., et al. (2016). Voriconazole-susceptible and voriconazoleresistant Aspergillus fumigatus coinfection. Am. J. Respir. Crit. Care Med. 193, 927-929. doi: 10.1164/rccm.201510-2104LE 
Kung, V. L., Chernock, R. D., and Burnham, C. D. (2018). Diagnostic accuracy of fungal identification in histopathology and cytopathology specimens. Eur. J. Clin. Microbiol. Infect. Dis. 37, 157-165. doi: 10.1007/s10096-017-3116-3

Mennink-Kersten, M. A., Donnelly, J. P., and Verweij, P. E. (2004). Detection of circulating galactomannan for the diagnosis and management of invasive aspergillosis. Lancet Infect. Dis. 4, 349-357. doi: 10.1016/S1473-3099(04)01045-X

Morio, F., Dannaoui, E., Chouaki, T., Cateau, E., Malard, O., Bonfils, P., et al. (2018). PCR-based detection of Aspergillus fumigatus and absence of azole resistance due to TR34/L98H in a french multicenter cohort of 137 patients with fungal rhinosinusitis. Mycoses 61, 30-34. doi: 10.1111/myc.12702

O'Sullivan, C. E., Kasai, M., Francesconi, A., Petraitis, V., Petraitiene, R., Kelaher, A. M., et al. (2003). Development and validation of a quantitative real-time PCR assay using fluorescence resonance energy transfer technology for detection of Aspergillus fumigatus in experimental invasive pulmonary aspergillosis. J. Clin. Microbiol. 41, 5676-5682. doi: 10.1128/JCM.41.12.5676-5682.2003

Paulussen, C., Hallsworth, J. E., Álvarez-Pérez, S., Nierman, W. C., Hamill, P. G., Blain, D., et al. (2017). Ecology of aspergillosis: insights into the pathogenic potency of Aspergillus fumigatus and some other aspergillus species. Microb. Biotechnol. 10, 296-322. doi: 10.1111/1751-7915.12367

Perlin, D. S., and Wiederhold, N. P. (2017). Culture-independent molecular methods for detection of antifungal resistance mechanisms and fungal identification. J. Infect. Dis. 216, S458-S465. doi: 10.1093/infdis/j ix121

Postina, P., Skladny, J., Boch, T., Cornely, O. A., Hamprecht, A., Rath, P. M., et al. (2018). Comparison of two molecular assays for detection and characterization of Aspergillus fumigatus triazole resistance and Cyp51A mutations in clinical isolates and primary clinical samples of immunocompromised patients. Front. Microbiol. 9:555. doi: 10.3389/fmicb.2018.00555

Rantakokko-Jalava, K., Laaksonen, S., Issakainen, J., Vauras, J., Nikoskelainen, J., Viljanen, M. K., et al. (2003). Semiquantitative detection by real-time PCR of Aspergillus fumigatus in bronchoalveolar lavage fluids and tissue biopsy specimens from patients with invasive aspergillosis. J. Clin. Microbiol. 41, 4304-4311. doi: 10.1128/JCM.41.9.4304-4311.2003

Salehi, E., Hedayati, M. T., Zoll, J., Rafati, H., Ghasemi, M., Doroudinia, A., et al. (2016). Discrimination of aspergillosis, mucormycosis, fusariosis, and scedosporiosis in formalin-fixed paraffin-embedded tissue specimens by use of multiple real-time quantitative PCR assays. J. Clin. Microbiol. 54, 2798-2803. doi: 10.1128/JCM.01185-16

Springer, J., McCormick Smith, I., Hartmann, S., Winkelmann, R., Wilmes, D., Cornely, O., et al. (2018a). Identification of Aspergillus and Mucorales in formalin-fixed, paraffin-embedded tissue samples: comparison of specific and broad-range fungal qPCR assays. Med. Mycol. doi: 10.1093/mmy/myy041 [Epub ahead of print].

Springer, J., White, P. L., Kessel, J., Wieters, I., Teschner, D., Korczynski, D., et al. (2018b). A comparison of Aspergillus and Mucorales PCR testing of different bronchoalveolar lavage fluid fractions from patients with suspected invasive pulmonary fungal disease. J. Clin. Microbiol. 56, e01655-e01617. doi: 10.1128/JCM.01655-17

Sugui, J. A., Kwon-Chung, K. J., Juvvadi, P. R., Latge, J. P., and Steinbach, W. J. (2014). Aspergillus fumigatus and related species. Cold Spring Harb. Perspect. Med. 5:a019786. doi: 10.1101/cshperspect.a019786

Ullmann, A. J., Aguado, J. M., Arikan-Akdagli, S., Denning, D. W., Groll, A. H., Lagrou, K., et al. (2018). Diagnosis and management of Aspergillus diseases: executive summary of the 2017 ESCMID-ECMM-ERS guideline. Clin. Microbiol. Infect. 24 (Suppl. 1), e1-e38. doi: 10.1016/j.cmi.2018. 01.002

White, P. L., Barnes, R. A., Springer, J., Klingspor, L., Cuenca-Estrella, M., Morton, C. O., et al. (2015). Clinical performance of Aspergillus PCR for testing serum and plasma: a study by the European Aspergillus PCR initiative. J. Clin. Microbiol. 53, 2832-2837. doi: 10.1128/JCM.00905-15

White, P. L., Posso, R. B., and Barnes, R. A. (2017). Analytical and clinical evaluation of the pathonostics aspergenius assay for detection of invasive aspergillosis and resistance to azole antifungal drugs directly from plasma samples. J. Clin. Microbiol. 55, 2356-2366. doi: 10.1128/JCM.00411-17

Conflict of Interest Statement: JM received grants from F2G and Merck. He has been a consultant to Scynexis and Merck and received speaker's fees from Merck, United Medical, TEVA and Gilead Sciences. PV received grants from Gilead Sciences, F2G, MSD, Thermo-Fisher and Pfizer.

The remaining authors declare that the research was conducted in the absence of any commercial or financial relationships that could be construed as a potential conflict of interest.

Copyright (C) 2018 de Groot, Hagen, Vreuls, Verweij, Chowdhary and Meis. This is an open-access article distributed under the terms of the Creative Commons Attribution License (CC BY). The use, distribution or reproduction in other forums is permitted, provided the original author(s) and the copyright owner(s) are credited and that the original publication in this journal is cited, in accordance with accepted academic practice. No use, distribution or reproduction is permitted which does not comply with these terms. 